\title{
Some Physical and Mechanical Properties of Upland Rice Seed (Maephurng Variety)
}

\author{
Nathaporn Suwanpayak ${ }^{1}$, Thirayut Wijitpap ${ }^{2}$, Patipat Srisongkram ${ }^{3}$, and Raumjit Nokkoul ${ }^{2}$
}

\begin{abstract}
Designing the agricultural equipment for production process and other postharvest have to require information about mechanical and physical properties. In this study, the physical and mechanical properties of upland rice seeds were determined at $4.16 \%$ of moisture content (wet basis). The seed was tested at $4.16 \%$ of moisture content which were the mean value of the length, the width and the thickness of $10.95 \pm 0.18 \mathrm{~mm}, 3.40 \pm 0.06$ and $2.14 \pm 0.03 \mathrm{~mm}$, respectively, equivalent diameter of $4.38 \pm 0.12 \mathrm{~mm}$, sphericity of $39.31 \pm 0.58$, aspect ratio of $0.31 \pm 0.02$, volume of $44.00 \pm 1.44 \mathrm{~mm}^{3}$, surface area of $52.86 \pm 1.13 \mathrm{~m}^{2}$, geometric mean diameter of $26.55 \pm 0.86 \mathrm{~mm}$, and arithmetic mean diameter of $5.50 \pm 0.20 \mathrm{~mm}$. The fundamental of seed dimensions are useful in calculating and creating a machine.
\end{abstract}

Keywords-Physical and mechanical properties, upland rice, seed dimensions, tensile strength.

\section{INTRODUCTION}

$\mathrm{R}$ ICE is one of the most important food and cereal for the world's human population. Rice varieties are produced by various cultivated area such as plain, highland and lowland depend on a weather atmosphere. Thailand has strongly rice and agricultural production which is needed water for these produce. However, water is the supply problems and shortages, especially the droughts in summer on the highland. So upland rice varieties are wildly cultivated at highland to solve this problem such as Pukaotong, Nangchuan, Lebnok, Dokkarm Kawdam, Nangkruan, Maephurng, Dumkatondum and Samduen varieties can be produced at Chumphon province in the southern Thailand [1], [2]. Maephurng varity is the local upland rice in Chumphon province which is produced by King Mongkut's Institute of Technology Ladkrabang Prince of Chumphon Campus (KMITL PCC). Upland rice (Maephurng variety) like a general characteristic of Black Glutinous Rice (BGR) is known as sticky black rice, whole grain of traditional sticky white rice, commonly served in Asian restaurants, especially Thai restaurants, BGR is sticky individual grains and can be used in sweet and savory Asian dishes. BGR can be purchased in Asian grocery stores and natural or health food store.

\footnotetext{
${ }^{1}$ Department of General Science, King Mongkut's Institute of Technology Ladkrabang Prince of Chumphon Campus, Chumphon, Thailand

${ }^{2}$ Department of Agricultural Technology, King Mongkut's Institute of Technology Ladkrabang Prince of Chumphon Campus, Chumphon, Thailand

${ }^{3}$ Central Laboratory, King Mongkut's Institute of Technology Ladkrabang Prince of Chumphon Campus, Chumphon, Thailand.
}

The physical and mechanical properties of seed production are a fundamental important for the design storage device, a processing machine and equipment used in postharvest. Many researches have studied the physical properties of soybean [3] hemp seed [4] and rice [5], [6] at a variation of moisture content. Recently, the upland rice was producesd [1], [2] Pukaotong, Nangchuan, Lebnok, Dokkarm, Kawdam, Nangkruan and Samduen varieties in organic farming at KMITL PCC which is one of the important productive institute of the upland rice seed in Thailand. The production of upland rice using organic farm is an alternative food safety and healthy product for the satisfy consumers.

In this study, Maephurng variety was selected to observe the mechanical characteristics at a moisture content of $4.16 \%$, in which characterization of the mechanical properties of the seeds is essential understand seed's behavior such as length $(L)$, width $(W)$ and thickness $(T)$. All this informational dimensions were induced to know the other physical properties.

\section{MATERIALS AND METHOD}

Maephurng verity used this experiment is produced in organic farming [1]. Rice seeds were collected in November 2014 from KMITL PCC organic farming. We measured the physical dimensions of the seeds at $4.16 \%$ of moisture content: length, width and thickness were determined randomly measuring of 100 seeds. The seed dimensions were measured by digital Vernier caliper and the moisture content was determined by Sartorious MA 37 moisture analyzer 105 ${ }^{\circ} \mathrm{C}$ (wet basis), water can cause undesirable change in the physical, chemical and mechanical properties of the solid material $[7,8]$.

The samples were measured by digital Vernier caliper with $0.02 \mathrm{~mm}$ accuracy at room temperature of $27{ }^{\circ} \mathrm{C}$, this experiment used the 100 seeds. Length, width and thickness can be calculated the surface area $(S)$, volume $(V)$, equivalent average diameter $\left(D_{p}\right)$, geometric mean diameter $\left(D_{g}\right)$, sphericity $(\phi)$, arithmetic mean diameter $\left(D_{e}\right)$ and aspect ratio $\left(R_{a}\right)$. All of the physical properties of the samples depend on seed dimensions, were given by [9]. Tensile strength of seeds at 0,6 and $24 \mathrm{~h}$ were determined by a food texture analyzer instrument (Lloyd Instruments Ltd, United Kingdom) with extension loads cell $50 \mathrm{~N}$ and speed $2 \mathrm{~mm} / \mathrm{min}$ equipped. 


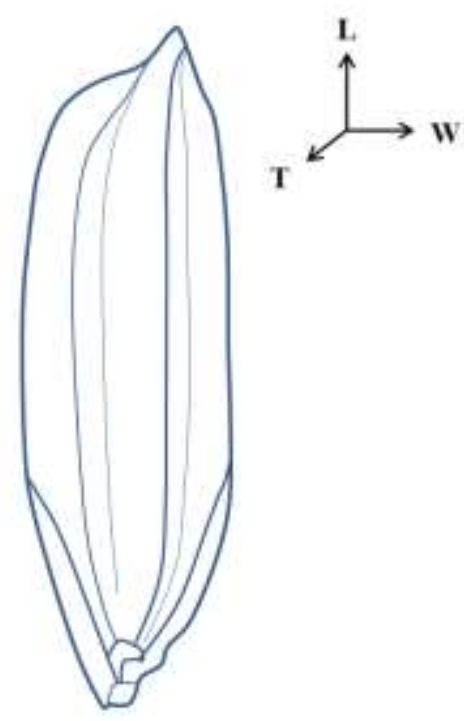

Fig. 1 Physical dimensions of the upland rice seed (Maephung variety).

The surface area, equipment diameter, geometric mean diameter, arithmetic mean diameter, sphericity and respect ratio are computed by equation from (1)-(7) as shown: seed surface area and volume were calculated by using [9]

$$
\begin{array}{r}
S=\frac{\pi L^{2} \sqrt{W T}}{2 L-\sqrt{W T}}, \\
V=0.25\left[\left(\frac{\pi}{6}\right) L(W+T)^{2}\right] .
\end{array}
$$

The equivalent diameter used to describe of the spherical materials with properties equivalent was calculated by [3]

$$
D_{p}=\left(L \frac{(W+T)}{4}\right)^{\frac{1}{3}} .
$$

The geometric mean diameter was determined [3] by

$$
D_{g}=(L W T)^{\frac{1}{3}} \text {. }
$$

Arithmetic mean diameter was calculated [10] as follow

$$
D_{e}=\frac{L+W+T}{3} .
$$

The sphericity described a spherical shape of the object was given [8] by the equation:

$$
\phi={\frac{(L W T)^{\frac{1}{3}}}{L}}^{\frac{1}{2}} \times 100 .
$$

The respect ratio was [9] as:

$$
R_{a}=\frac{W}{L} .
$$

\section{RESULTS AND DISCUSSION}

The values distribution of frequency of the upland rice seed dimensions at $4.16 \%$ moisture content are showed at Fig. 1.
The range of seed thickness was from 1.80 to $2.30 \mathrm{~mm}$, width ranging from 3.10 to $3.60 \mathrm{~mm}$ and length was from 9.0-12.0 $\mathrm{mm}$. A linear model for descriped mass and length of upland rice (Maephurng variety) at $4.16 \%$ moisture content was showed in Fig. 2.

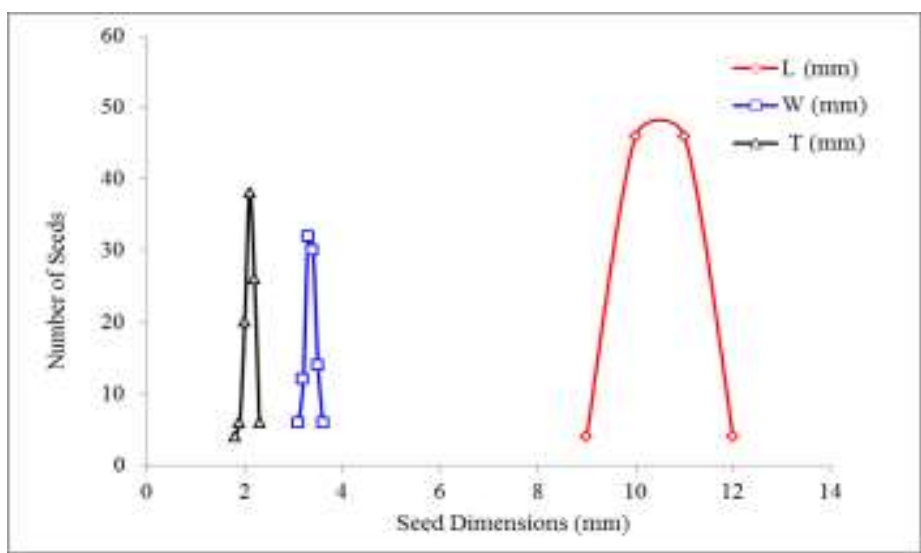

Fig. 2 The values distribution curves of upland rice dimensions at the moisture content of $4.16 \%$

The seeds dimensions varied between mass and length can be measured $10.95 \pm 0.18 \mathrm{~mm}$ length; $3.40 \pm 0.06 \mathrm{~mm}$ width; $2.14 \pm 0.03 \mathrm{~mm}$ thick; and a mass $0.034 \pm 12 \mathrm{~g}$. Size and mass of seeds were relatively constant, was estimated with a determiantion coefficient as 0.126 . The mechanical properties of seed, was compressed between two cylindrical rods of the equipment along the horizontal axis until fracture occurred (fracture point). The fracture yield point is a point on the compression force-deformation curve at which the load specimen shows a observe failure in the form of cracks or breaks. The physical properties of seeds were determined by a food texture analyzer instrument with extension load cell 50 $\mathrm{N}$ and speed $2 \mathrm{~mm} / \mathrm{min}$ equipped.

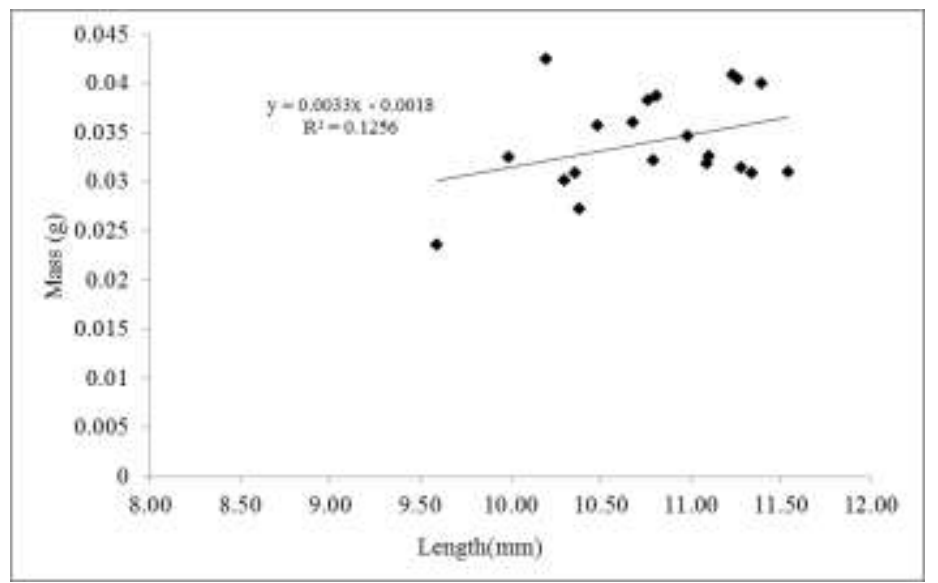

Fig. 3 Relationship between upland rice seeds mass and length (Maephung variety).

The points were detected by a continuous decrease of the compression force, while the fracture point was detected when the loading was stopped. Yield stress is well respect to the mechanical and engineering properties for material and food analysis. The determination of yield stress of upland rice seed 
as showed in Fig.4, comparison of water uptake by seeds were measured at 6,12 and $24 \mathrm{~h}$ of imbibition. The measuring results were shown the highest of tensile strength of soaking at $24 \mathrm{~h}$.

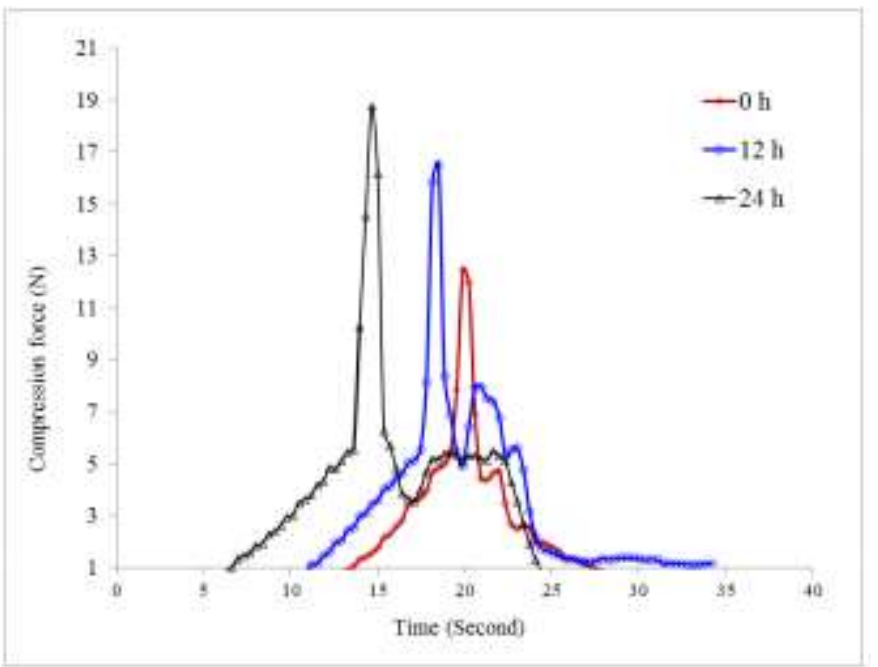

Fig. 4 The fracture yield points of a seed soaking at $0 \mathrm{~h}, 12 \mathrm{~h}$ and 24 h.

M. Ghasemi Varnamkhastia [7] reported that thousand grain weight values of Sorkheh and Sazandegi cultivars were 21.64 and 20.52 , respectively. There is a useful index to milling outturn foreign material in a measuring the relative amount of rough rice. The results have shown the dimensions and mechanical characteristics of the upland rice (Maephurng variety) at $4.16 \%$ of moisture content in Table 1 . The average value of the length, the width and the thickness were $10.95 \pm 0.18 \mathrm{~mm}, \quad 3.40 \pm 0.06 \mathrm{~mm}$ and $2.14 \pm 0.03 \mathrm{~mm}$, respectively.

TABLE I: SOME PHySiCAL PROPERTIES OF UPLAND Rice SEED (MAEPHURNG VARIETY)

\begin{tabular}{lcc}
\hline \hline \multicolumn{1}{c}{ Properties } & $\begin{array}{c}\text { No. of } \\
\text { OBSERVATION }\end{array}$ & \multicolumn{1}{c}{ Mean } \\
\hline Length (mm) & 100 & $10.95 \pm 0.18$ \\
Width (mm) & 100 & $3.40 \pm 0.06$ \\
Thickness (mm) & 100 & $2.14 \pm 0.03$ \\
Equivalent diameter (mm) & 100 & $4.38 \pm 0.12$ \\
Sphericity (\%) & 100 & $39.31 \pm 0.58$ \\
Aspect ratio & 100 & $0.31 \pm 0.02$ \\
Volume (mm $\left.{ }^{3}\right)$ & 100 & $44.00 \pm 1.44$ \\
Surface area $\left(\mathrm{mm}^{2}\right)$ & 100 & $52.86 \pm 1.13$ \\
Geometric mean diameter $(\mathrm{mm})$ & 100 & $26.55 \pm 0.86$ \\
Arithmatic mean diameter $(\mathrm{mm})$ & 100 & $5.5 \pm 0.20$ \\
1000 seed weight $(\mathrm{g})$ & 5 & $28.68 \pm 0.26$ \\
& & \\
\hline \hline
\end{tabular}

In addition, surface area, volume, geometric mean diameter, arithmetic mean diameter, shericity and aspect ratio were $52.86 \pm 1.13 \mathrm{~mm}^{2}, 44.00 \pm 1.44 \mathrm{~mm}, 26.55 \pm 0.86 \mathrm{~mm}$, $5.5 \pm 0.20 \mathrm{~mm}, 39.31 \pm 0.58$ and $0.31 \pm 0.02$, respectively. All the parameters can be computed by using the seed dimensions.

\section{CONCLUSION}

The paper concluded on the engineering properties and characteristic dimension of upland rice (Maephung variety). Some physical properties: length, width, thickness, surface area, volume, equivalent average diameter, geometric mean diameter, sphericity, arithemetic mean diameter and aspect ratio were to investigate the fundamental information of an agricultural machine design and postharvest technology and engineering. The mechanical properties are defined the characteristic of material and food production under applied forces. However, this experiment was used only one treatment of the seeds dimension to considering physical properties and three treatment of moisture content to fracture point of upland rice for designing seed machine and seed production.

\section{ACKNOWLEDGMENT}

The authors would like to thank King Mongkut's Institute of Technology Ladkrabang Prince of Chumphon Campus for providing the financial support and also thank Department of Agricultural Engineering for support the Sartorius MA37 moisture analyzer.

\section{REFERENCES}

[1] R. Nokkoul, "Organic upland rice seed production," Advance J. Food Sci. Tech., vol.6, no.12, pp.1313-1317, 2014.

[2] R. Nokkoul and T. Wichitparp, "Quality of local upland rice seeds produced under organic farming system," As. J. Food Ag-Ind., Special Issue, pp. 343-348, 2009.

[3] H. Kibar and T. Öztürk, "Physical and mechanical properties of soybean," Int. Agrophysics, vol.22, pp. 239-244, 2008.

[4] A. Taheri-Garavand, A. Nassiri and S.M.T. Gharibzahedi, "physical and mechanical properties of hemp seed," Int. Agrophys., vol. 26, pp. 211-215, 2012.

http://dx.doi.org/10.2478/v10247-012-0031-9

[5] P.C. Corre^a, F. Schwanz da Silva, C. Jaren, P.C. Afonso Junior and I. Arana, "Some physical properties of rough rice (Oryza Sativa L.) grain," $J$. Food Eng., vol. 79, pp.137-142, 2007.

[6] M. Jouki and N. Khazaei, "Some physical properties of rice seed (Oryza sativa)," Res. J. Appl. Sci. Eng. Tech., vol. 4, no.13, pp. 1846-1849, 2012.

[7] G. N. Al-Karaki, "Seed size and water potential effects on water uptake, germination and growth of lentil," J. Agronomy \& Crop Science, vol.181, pp. 237-242, 1998.

http://dx.doi.org/10.1111/j.1439-037X.1998.tb00423.x

[8] A. Lakatos, "Initial state sorption measurements," Appl. Mech. Material, Doi:10.4028, 2016.

[9] M. G. Varnamkhastia, H. Moblia, A. Jafaria, A.R. Keyhani M. Heidari Soltanabadib, S. Rafieea and K. Kheiralipour, "Some physical properties of rough rice (Oryza Sativa L.) grain,” J. Cereal Sci., vol.47, pp.496-501, 2008.

http://dx.doi.org/10.1016/j.jcs.2007.05.014

[10] L. Crataeguspontica, "Physical and nutritional properties of hawthorn fruit," Agr. Eng. Int., vol.17, no.1, pp.232-237, 2015 